\title{
OPTIMALISASI SEKTOR PERTANIAN DI PROVINSI JAWA TENGAH UNTUK PEMBERDAYAAN PETANI MELALUI APLIKASI HALAL TANI
}

\author{
Naufal Haidar Farras, Muhammad Rizki F, Aulia Ramadhan \\ Universitas Diponegoro Semarang \\ naufalhf.1998@gmail.com
}

\begin{abstract}
Abstrak
Sektor pertanian memiliki kontribusi terhadap pembangunan, salah satunya di Provinsi Jawa Tengah. Provinsi di pulau jawa yang mempunyai kontribusi sektor pertanian paling tinggi terhadap PDRB yaitu sebesar. Dengan data tersebut, seharusnya petani dapat hidup sejahtera. Namun kenyataannya petani di Jawa Tengah memiliki kualitas hidup yang jauh dari kata layak, diantaranya pendapatan dan produktivitas yang rendah, kesulitan dalam pengajuan kredit, pendidikan rendah serta sistem irigasi yang belum optimal. Selain itu, nilai tukar petani pada Januari 2018 sebesar 103,00. Turun sebesar 0,48 dari bulan Desember 2017 yaitu sebesar 103,47.

Fokus penelitian ini adalah bagaiamana mengoptimalkan potensi sektor pertanian di Jawa Tengah dengan program pemberdayaaan sumberdaya yang ada melalui aplikasi Halal Tani berbasis financial technology (fintech).

Penulisan karya ilmiah ini dilakukan dengan studi literatur yang mendalam, yakni dengan menggunakan penulisan kualitatif deskriptif. Metode pengumpulan data dengan metode kepustakaan, dokumenter, intuitif subjektif. Proses analisis data yang dilakukan dalam penulisan ini terjadi secara bolak balik dan berinteraktif, yang terdiri dari: pengumpulan data (data collection), reduksi data (data reduction), penyajian data (data display) dan analisis dan Pembahasan.

Hasil penelitian ini adalah bahwa dengan adanya program pemberdayaan bagi pelaku pertanian melalui Halal Tani, dapat meningkatkan taraf hidup petani, produktivitas meningkat, serta mudah mengajukan kredit usaha tani.
\end{abstract}

Keyword : Pertanian, Pemberdayaan, Fintech, Halal Tani 


\section{Pendahuluan}

Indonesia merupakan negara agraris yang memiliki potensi pertanian yang sangat menjanjikan. Faktor iklim, geologis dan letak geografis yang strategis menjadikan Indonesia memiliki peluang yang besar dalam mengembangkan usaha dalam bidang pertanian. Baik dalam bidang kehutanan, perkebunan, ataupun perikanan masing masing memiliki peluang yang cukup guna bersaing dengan negara lain.

Melirik negara tetangga yang berhasil dalam memaksimalkan sektor pertaniannya seperti Vietnam, Thailand dan Filipina seharusnya hal tersebut menjadi motivasi masyarakat Indonesia untuk lebih berusaha memajukan dunia pertanian di negara ini. Karena secara sumber daya Indonesia tidak kalah dengan negara-negara tersebut, bahkan melebihi.

Terbukti dari jumlah lahan pertanian di Indonesia yang mencapai sekitar 41.5 juta Ha dengan pembagian yaitu Hortikultura 567 ribu Ha, Tanaman Pangan 19 juta Ha, dan Tanaman Perkebunan 22 Juta Ha (Kementan RI, 2014). Sayangnya, luasnya lahan pertanian tersebut tidak diimbangi dengan banyaknya jumlah petani yang tiap tahun terus menurun yaitu data dari BPS yang menyebutkan jumlah penduduk yang bekerja di sektor pertanian terus menurun dari 39,22 juta pada 2013 menjadi 38,97 juta pada 2014 (Kementan RI, 2014).

Padahal, sektor pertanian merupakan salah satu sumber kehidupan bagi sebagian penduduk Indonesia. Agenda mewujudkan kemandirian ekonomi melalui kedaulatan pangan pada tahun 2015-2019 perlu kembali dilanjutkan, dimana Indonesia sudah memasuki kelas Upper Middle Income dan pertanian memasuki tahapan menuju industri. Salah satu provinsi yang memiliki potensi besar dalam bidang pertanian adalah Provinsi Jawa Tengah.

Jawa Tengah merupakan provinsi yang terletak di bagian tengah Pulau Jawa. Luas wilayahnya $32.548 \mathrm{~km}^{2}$, atau sekitar 25,04\% dari luas pulau Jawa. Kepulauan Karimun Jawa di Laut Jawa termasuk bagian dari provinsi Jawa Tengah

Jenis tanah wilayah Jawa Tengah didominasi oleh tanah latosol, aluvial, dan gromosol, sehingga hamparan tanah di provinsi ini termasuk tanah yang mempunyai tingkat kesuburan yang relatif baik. Kondisi ini membuat membuat pertanian dan perkebunan merupakan sektor unggulan di Jawa Tengah.

Kontribusi sektor pertanian terhadap perekonomian Provinsi Jawa Tengah terlihat dari nilai Pendapatan Domestik Regional Bruto (PDRB). Menurut Badan Pusat Statistik (BPS) Provinsi Jawa Tengah tahun 2011, sektor pertanian menjadi sektor terbesar ketiga dalam PDRB sebesar 17,87 persen setelah sektor industri pengolahan (33,06 persen) dan sektor perdagangan, hotel dan restoran (21,73 persen). Hasil produksi sektor pertanian bermanfaat sebagai input bagi sektor ekonomi lainnya, khususnya sektor modern.

Beberapa komoditi unggulan dari sektor pertanian dan perkebunan di Jawa Tengah adalah padi, jagung, karet, kopi, teh, kelapa, tebu, dan kakao. Hampir di seluruh daerah di Jawa Tengah merupakan penghasil jagung, kecuali Magelang dan 
Pekalongan.Untuk pengembangan komoditas karet, dipusatkan di Kecamatan Wanareja dan Dayeuh Luhur Kabupaten Cilacap, Banyumas, Banjarnegara, dan Kendal.Wonosobo, Karanganyar, Tegal, Batang, Temanggung, Kendal, Pekalongan, Pemalang, Tegal, Brebes, Banyumas, Purbalingga, Banjarnegara, Magelang, dan Boyolali merupakan sentra produksi teh. Sebagian besar daerah di Jawa Tengah juga merupakan penghasil kelapa.

Namun Berdasarkan data BPS, 1,7 juta jiwa penduduk Jawa Tengah masih menjadi pengangguran dan berada di bawah garis kemiskinan. Selain itu, nilai tukar petani pada Januari 2018 sebesar 103,00. Turun sebesar 0,48 dari bulan Desember 2017 yaitu sebesar 103,47. Hal ini menunjukkan penurunan kesejahteraan dari para petani di Jawa Tengah.

Salah satu cara untuk meningkatkan tingkat pendapatan yang dihasilkan petani yaitu dengan cara memotong alur distribusi penjualan beras melalui tengkulak dan menghilangkan peran rentenir dalam memberikan modal serta mengurangi tingkat penurunan lahan persawahan. Dalam konteks ini, menciptakan lahan pertanian abadi dan peningkatan kesejahteraan petani atau pengentasan kemiskinan merupakan tujuan ganda yang bersifat inklusif dengan peningkatan ksejahteraan petani yang ada di Indonesia. Dimana para petani menjual hasil panennya tersebut, langsung ke kosumen seperti restoran, hotel, dan masyarakat perkotaan. Hal tersebut dapat dicapai dengan memanfaatkan teknologi sistem informasi untuk dapat memudahkan serta menghubungkan secara langsung antara petani kepada konsumen.

Untuk meningkatkan sektor pertanian di Provinsi Jawa Tengah dibutuhkan salah satu sistem pertanian baru yang sesuai dengan syariah, mengelola secara terstruktur dan sinergis yang mencakup fungsi koordinasi, perencanaan, implementasi, dan pengendalian sistem pertaniaan secara inovatif dan sistematik melalui pemanfaatan jejaring, informasi dan teknologi, yang terpimpin secara terpadu dengan peran serta masyarakat, pelaku/asosiasi, industri, akademisi dan pemerintah yang memiliki tujuan, proses dan kepentingan bersama dalam rangka meningkatkan kualitas hasil pangan serta kesejahteraan petani.

Sebagai solusi untuk meningkatkan potensi pertanian di Jawa Tengah serta meningkatkan kesejahteraan petani, Salah satunya dengan mengembangkan sebuah sistem yang mengaplikasikan financial technology untuk kemudahan akses para pelaku bisnis di bidang pertanian. Untuk itu penulis berencana membuat karya tulis berjudul

\section{“Optimalisasi Sektor Pertanian di Provinsi Jawa Tengah untuk Pemberdayaan Petani melalui Aplikasi Halal Tani”.}

\section{Tinjauan Pustaka}

1. Kondisi Pertanian Jawa Tengah

Sektor pertanian memiliki kontribusi terhadap pembangunan terutama di daerah, salah satunya di Provinsi Jawa Tengah. Pembangunan ekonomi daerah erat kaitannya dengan industrialisasi dan peran sektor pertanian mulai tergantikan oleh sektor industri. Pembangunan ekonomi daerah bertujuan untuk meningkatkan jumlah dan jenis peluang kerja untuk masyarakat daerah. Tolak ukur keberhasilan pembangunan perekonomian 
daerah dapat dilihat dari pertumbuhan ekonomi dan struktur ekonomi. Berikut tingkat kontribusi sektor pertanian Provinsi Jawa Tengah terhadap PDRB yang ditampilkan pada Tabel 2.1.

\section{Tabel 1}

\section{Tingkat Kontribusi Sektor Pertanian Terhadap PDRB Menurut Provinsi di Pulau Jawa}

\begin{tabular}{|l|l|l|}
\hline No & Provinsi & Kontribusi Sektor Pertanian (persen) \\
\hline 1 & DKI Jakarta & 0,07 \\
\hline 2 & Jawa Barat & 13,1 \\
\hline 3 & Banten & 7,8 \\
\hline 4 & Jawa Tengah & 18,7 \\
\hline 5 & DI Yogyakarta & 17,3 \\
\hline 6 & Jawa Timur & 15,0 \\
\hline & Jumlah & 100 \\
\hline
\end{tabular}

Sumber: Statistika Indonesia, 2010

Tabel 1 menjelaskan di pulau jawa provinsi yang mempunyai kontribusi sektor pertanian paling tinggi terhadap PDRB yaitu Provinsi Jawa Tengah (18,7 \%). DKI Jakarta (0,07\%), Jawa Barat (13,1\%), Banten (7,8 \%), Jawa Tengah (18,7\%), DI Yogyakarta $(17,3 \%)$ dan Jawa Timur (15,0\%). Meskipun Jawa Tengah yang memiliki tingkat tertinggi kontribusi sektor pertanian terhadap PDRB tetapi laju pertumbuhan sektor pertanian ada dalam keadaan stagnasi atau bahkan dikatakan mundur (Suwanti \& Gunanto, 2013).

Salah satu faktor penyebab kurangnya produktivitas pertanian adalah sumber daya manusia yang masih rendah dalam mengolah lahan pertanian dan hasilnya. Mayoritas petani di Indonesia masih menggunakan sistem manual dalam pengolahan lahan pertanian. Selain itu terdapat kesulitan dalam pengajuan kredit, pendidikan rendah serta sistem irigasi yang belum optimal.

2. Pemberdayaan Ekonomi Umat dalam Perspektif Ekonomi Syariah

Pemberdayaan secara bahasa, dari bahasa Indonesia yang berasal dari kata "daya" yang berarti kekuatan, yang mana secara istilah bermakna: Upaya untuk membangun daya yang dimiliki kaum dhuafa dengan mendorong, memberikan motivasi, dan meningkatkan kesadaran tentang potensi yang dimilikinya dan berusaha mengembangkannya (Farid, 2000).

Umat Islam merindukan kejayaan dan kemakmuran seperti yang terjadi pada masa khalifah Umar bin Abd al-'Aziz. r.a. khalifah yang terkenal adil, padahal beliau menjabat khalifah hanya tigapuluh bulan, pada waktu itu semua orang yang punya hutang bisa mendapatkan bantuan dari khas Negara, semua kebutuhan pokok terpenuhi, setelah semua kebutuhan pokok terpenuhi beliau memberikan bantuan kepada para petani kecil untuk mengelola lahannya dengan baik, dengan memberikan kredit dari khas Negara. Kebijakan ini sudah ada beberapa ratus tahun sebelum dunia mengenal bank perkreditan 
untuk pertanian. Sebelum masa Umar bin Abd 'Aziz yaitu pada masa Umar bin Khattab pada waktu itu tidak ada seorangpun yang mau menerima zakat. Demikian kesejahteraan di bawah naungan keadilan Islam sampai pada taraf dimana semua yang memiliki hak bisa mendapatkanya (Qaradhawi, 2002).

Kesimpulannya, bahwa kewajiban dan tuntunan agama yang ditetapkan Allah, tidak mempunyai tujuan lain kecuali untuk kemaslahatan umat manusia. Allah menghendaki keharmonisan hubungan antara seluruh mahluk-Nya, demi mencapai kebahagiaan di dunia dan akhirat.

3. Perkembangan Financial Technology

Financial technology (FinTech) merupakan perpaduan inovasi antara pengembangan teknologi dan keuangan yang mengubah model bisnis saat ini dan melemahkan barrier to entry (Bank Indonesia, 2016). Perubahan model bisnis terlihat dari berbagai layanan keuangan yang dilakukan menerapkan suatu konsep yang berbeda dari sebelumnya. Berkaitan dengan melemahnya barrier to entry, memberikan peran bagi FinTech dalam memuncukan pelaku-pelaku unregulated yang menjalankan layanan sebagaimana institusi regulated (Bank Indonesia, 2016). Perkembangan FinTech sebenarnyalah bukanlah merupakan fenomena baru dimana jejaknya dapat ditelusuri sejak abad ke-17 sebagaimana evolusi teknologi keuangan berikut:

\section{Gambar 1}

\section{Evolusi Financial Technology}

\begin{tabular}{|c|c|c|c|c|c|}
\hline \multicolumn{2}{|r|}{1800 s } & \multicolumn{2}{|r|}{$1900 \mathrm{~s}$} & \multicolumn{2}{|r|}{20005} \\
\hline $\begin{array}{l}1838 \\
1865 \\
\text { Late } \\
1800\end{array}$ & $\begin{array}{l}\text { Telegraph } \\
\text { Trans-Atlantic Cable } \\
\text { Exchange goods using } \\
\text { credit }\end{array}$ & $\begin{array}{l}1918 \\
1950 \\
1960 \\
1966 \\
1967 \\
1970 \\
1971 \\
1973 \\
1982 \\
1983 \\
1984 \\
1987 \\
1993 \\
1998 \\
1999\end{array}$ & $\begin{array}{l}\text { Fedwire established } \\
\text { Diners ( } 1^{\text {st }} \text { Credit Card) } \\
\text { 1st Stock Market System (Quotron) } \\
\text { Telex } \\
1^{\text {st }} \text { ATM (Barclasys) } \\
\text { Clearing House } \\
\text { NASDAQ } \\
\text { SWIFT } \\
1^{\text {st }} \text { Online Brokerage } \\
1^{\text {st }} \text { Online Banking } \\
1^{\text {st }} \text { Online Shopping } \\
\text { Black Monday } \\
\text { - Fintech is coined as a term } \\
\text { - Fintech Consortium (Citicorp) } \\
\text { - Majority US Bank set up internet banking } \\
\text { - Paypal } \\
\text { Alibaba }\end{array}$ & $\begin{array}{l}2008 \\
2009 \\
2014 \\
2015\end{array}$ & $\begin{array}{l}\text { - Financial Crisis } \\
\text { - Wealthfront } \\
\text { - MPesa } \\
\text { Square } \\
\text { Apple Pay } \\
\text { - Samsung Pay } \\
\text { - "Smile to Pay" } \\
\text { (Alibaba) }\end{array}$ \\
\hline
\end{tabular}

Sumber: New York Times, 2016

Bidang usaha FinTech merupakan layanan keuangan berbasis digital yang terbentang mulai dari sistem pembayaran, layanan perbankan, layanan asuransi, pinjaman, urun dana, hingga sekedar advis atau pembelajaran kepada masyarakat melalui media digital. Secara umum, layanan keuangan berbasis digital yang saat ini telah berkembang di Indonesia dapat dibedakan ke dalam beberapa kelompok, yaitu (1) payment channel/system, yaitu layanan elektronik yang menggantikan uang kartal dan uang giral sebagai alat pembayaran; (2) digital banking,teknologi digital untuk memenuhi kebutuhan nasabah seperti ATM, EDC, internet banking, mobile banking, SMS banking, phone banking, dan video banking; (3) online/digital insurance, layanan asuransi bagi nasabah dengan memanfaatkan teknologi digital, (4) Crowdfunding, kegiatan pengumpulan dana melalui 
website atau teknologi digital lainnya untuk tujuan investasi maupun sosial, dan (5) Peer-toPeer (P2P) Lending, layanan keuangan yang memanfaatkan teknologi digital untuk mempertemukan antara pihak yang membutuhkan pinjaman dan pihak yang bersedia memberikan pinjaman.

\section{Metode Penelitian}

1. Jenis Penulisan dan Pendekatan Penulisan

Penulisan karya ilmiah ini dilakukan dengan kegiatan studi literatur yang mendalam, yakni dengan menggunakan penulisan deskriptif dan data yang digunakan merupakan data pendekatan kualitatif. Pendekatan kualitatif adalah prosedur yang menghasilkan data-data deskriptif, yang meliputi kata-kata tertulis atas objek penulisan yang sedang dilakukan yang didukung oleh studi literatur berdasaran pengalaman kajian pustaka, baik berupa data penulisan maupun angka yang dapat dipahami dengan baik (Lexy, 2013). Di samping itu, pendekatan kualitatif lebih peka dan dapat menyesuaikan diri dengan banyak penajaman pengaruh bersama serta pola-pola nilai yang dihadapi di lapangan. Metode deskriptif adalah suatu metode dalam meneliti status sekelompok manusia, suatu objek, suatu sistem pemikiran, ataupun suatu kelas peristiwa pada masa sekarang (Danu, 2015). Tujuan dari penulisan deskriptif ini adalah untuk membuat deskripsi, gambaran atau lukisan secara sistematis, faktual dan akurat mengenai faktafakta, sifat serta hubungan antar fenomena yang diselidiki.

2. Jenis Data dan Metode Pengumpulan Data

Data yang dikumpulkan dalam penulisan ini adalah data sekunder, yaitu sumber data penulisan yang diperoleh secara tidak langsung melalui media perantara. Data sekunder umumnya berupa bukti, catatan, atau laporan historis yang telah tersusun dalam arsip (data dokumenter), baik yang dipublikasikan maupun tidak dipublikasikan. Metode pengumpulan data yang digunakan didalam penulisan ini adalah dengan metode kepustakaan, dokumenter, intuitif subjektif.

Studi kepustakaan dilakukan dengan jalan membaca literatur-literatur yang berkaitan dan menunjang penulisan ini, berupa pustaka cetak maupun elektronik (datadata internet). Studi dokumentasi dilakukan dengan jalan membaca laporan-laporan penulisan sebelumnya serta artikel yang diakses dari internet, buku maupun jurnal yang sesuai dengan permasalahan. Pada metode ini penulis hanya memindahkan data yang relevan dari suatu sumber atau dokumen yang diperlukan. Selanjutntnya intuitif subjektif merupakan perlibatan pendapat penulis atas masalah yang sedang dibahas.

3. Metode Analisis Data

Sehubungan dengan permasalahan yang tertulis pada rumusan masalah dan pendekatan penulisan yang digunaan, penulis menganalisa data-data yang diperoleh dengan metode analisis deskriptif kualitatif, yaitu data yang diperoleh kemudian disusun, sehingga mempermudah pembahasan masalah-masalah yang ada. Karena titik fokus penulisan ini adalah penulisan berbasis literatur (pustaka), maka data yang diumpulkan merupakan data kualitatif. Proses analisis data yang dilakukan dalam penulisan ini terjadi 
secara bolak balik dan berinteraktif, yang terdiri dari: pengumpulan data (data collection), reduksi data (data reduction), penyajian data (data display) dan analisis dan Pembahasan.

\section{Hasil dan Pembahasan}

1. Potensi Pertanian di Provinsi Jawa Tengah

Pertumbuhan ekonomi dipengaruhi oleh peningkatan hasil produksi sektor-sektor ekonomi pada daerah yang bersangkutan. Hasil produksi secara langsung tercermin pada besarnya Produk Domestik Bruto (PDB) suatu Negara, atau besarnya Produk Domestik Regional Bruto (PDRB) suatu daerah provinsi atau kota. Dalam pandangan tradisional, pertumbuhan ekonomi adalah baik apabila PDB atau PDRB meningkat dari tahun ke tahun. Untuk mencapai hal tersebut, pemerintah berupaya mengoptimalkan hasil-hasil daerah yang ada guna berproduksi secara efektif (Tamyawan, 2012).

Provinsi Jawa Tengah terletak diantara $5^{\circ} 40^{\prime}$ dan $8^{\circ} 30^{\prime}$ Lintang Selatan dan antara $108^{\circ} 30^{\prime}$ dan $111^{\circ} 30^{\prime}$ Bujur Timur (termasuk Pulau Karimunjawa). Provinsi Jawa Tengah terbagi menjadi 29 kabupaten dan 6 kota. Luas wilayah Jawa Tengah pada tahun 2010 tercatat seluas 3,25 juta hektar atau sekitar 25,04 persen dari luas Pulau Jawa (1,70 persen dari luas Indonesia). Luas yang ada, terdiri dari 992 ribu hektare (30,47 persen) lahan sawah (Agustono, 2013).

Kontribusi sektor pertanian terhadap perekonomian Provinsi Jawa Tengah terlihat dari nilai Pendapatan Domestik Regional Bruto (PDRB). Menurut Badan Pusat Statistik (BPS) Provinsi Jawa Tengah tahun 2011, sektor pertanian menjadi sektor terbesar ketiga dalam PDRB sebesar 17,87 persen setelah sektor industri pengolahan (33,06 persen) dan sektor perdagangan, hotel dan restoran (21,73 persen). Hasil produksi sektor pertanian bermanfaat sebagai input bagi sektor ekonomi lainnya, khususnya sektor modern.

Menurut data BPS Provinsi Jawa Tengah tahun 2011, penyerapan tenaga kerja di sektor pertanian sebesar 5.376.452 juta jiwa (33,78 persen), angka ini jauh lebih tinggi di atas sektor perdagangan, hotel dan restoran (21,38 persen) dan industri pengolahan (19,14 persen). Jumlah tenaga kerja sektor pertanian Provinsi Jawa Tengah merupakan yang terbesar kedua di tingkat nasional atau sebesar 13,67 persen dari 39.328.915 jiwa total tenaga kerja sektor pertanian di Indonesia (BPS Indonesia, 2012). Secara nasional, sektor pertanian Provinsi Jawa Tengah berkontribusi dalam penyerapan tenaga kerja sebesar 4,90 persen dari jumlah total tenaga kerja di Indonesia.

Suwanti \& Gunanto (2013) menjelaskan bahwa provinsi di pulau jawa yang mempunyai kontribusi sektor pertanian paling tinggi terhadap PDRB yaitu Provinsi Jawa Tengah (18,7 \%). DKI Jakarta (0,07 \%), Jawa Barat (13,1\%), Banten (7,8 \%), DI Yogyakarta $(17,3 \%)$ dan Jawa Timur (15,0\%). Meskipun Jawa Tengah yang memiliki tingkat tertinggi kontribusi sektor pertanian terhadap PDRB tetapi laju pertumbuhan sektor pertanian ada dalam keadaan stagnasi atau bahkan dikatakan mundur. Prioritas utama pembangunan ekonomi di sektor modern mampu mendorong pertumbuhan PDRB Provinsi Jawa Tengah secara lebih cepat. Sektor modern lebih mengutamakan teknologi daripada tenaga manusia, sehingga pertumbuhan PDRB yang dicapai belum 
tentu mendorong distribusi pendapatan secara merata. Keadaan tersebut menjadi dasar permasalahan bagaimana pertumbuhan pendapatan daerah yang terlalu tinggi justru dapat meningkatkan ketimpangan pendapatan antar daerah. Pertumbuhan ekonomi dicapai harus menciptakan kesejahteraan secara merata, bukan sekedar pertumbuhan yang tinggi.

Salah satu cara untuk meningkatkan tingkat pendapatan yang dihasilkan petani yaitu dengan cara memotong alur distribusi penjualan beras melalui tengkulak dan menghilangkan peran rentenir dalam memberikan modal serta mengurangi tingkat penurunan lahan persawahan. Dalam konteks ini, menciptakan lahan pertanian abadi dan peningkatan kesejahteraan petani atau pengentasan kemiskinan merupakan tujuan ganda yang bersifat inklusif dengan peningkatan ksejahteraan petani yang ada di Indonesia. Dimana para petani menjual hasil panennya tersebut, langsung ke kosumen seperti restoran, hotel, dan masyarakat perkotaan. Hal tersebut dapat dicapai dengan memanfaatkan teknologi sistem informasi untuk dapat memudahkan serta menghubungkan secara langsung antara petani kepada konsumen.

Saat ini bisnis financial technology (fintech) semakin meluas. Tidak hanya menyasar sektor Usaha Mikro Kecil dan Menengah (UMKM), kini bermunculan pula fintech yang fokus menggarap sektor pertanian. Dalam kondisi tersebut seharusnya bisa menjadi solusi bagi Pemerintah Daerah untuk membentuk kemitraan bersama stakeholder terkait untuk menciptakan lapangan kerja dan mendorong pertumbuhan ekonomi daerah terutama dalam sektor pertanian. Pertumbuhan ekonomi yang dicapai haruslah mampu mengurangi angka kemiskinan dengan mengurangi kesenjangan pendapatan antar penduduk, antar daerah, dan antar sektor di Provinsi Jawa Tengah.

2. Stakeholder yang Terlibat Dalam Pemberdayaan Petani Melalui Aplikasi Halal Tani

Pemerintah daerah berperan penting menjalankan progam pemberdayaan petani melalui aplikasi Halal Tani, karena perangkat hukum dan regulasi dari pemerintah pusat dan daerah melalui kolaborasi pihak-pihak yang berkepentingan maka akan menciptakan harmonisasi antara regulator dan para stakeholder lainnya. Dengan dikomandoi Dinas Pertanian dan Perkebunan (DISTANBUN) Provinsi Jawa Tengah yang dibawahi oleh lembaga yang mendukung kemajuan pertanian provinsi Jawa Tengah antara lain Majelis Ulama Indonesia (MUI), Masyarakat Ekonomi Syariah (MES), Otoritas Jasa Keuangan (OJK) dan Akademisi dan Praktisi.

Majelis Ulama Indonesia (MUI) yaitu sebagai lembaga yang mengeluarkan fatwa halal pada setiap produk atau jasa yang ada pada setiap produk yang dihasilkan oleh petani. Kemudian masyarakat Ekonomi Syariah (MES) debagai organisasi ekonomi syariah yang mendukung penuh, selanjutnya Otoritas Jasa Keuangan (OJK) bertugas sebagai regulator industri keuangan yang menjamin landasan operasional Fintech serta perlindungan terhadap konsumen. Terakhir Akademisi dan Praktisi yang bertugas sebagai pihak yang membantu dalam hal riset dan teknologi agar pertanian Indonesia selalu menciptakan produk baru dan hasil yang berkualitas serta dikenal masyarakat dunia. 
Dengan adanya kolaborasi antar stakeholder diatas maka diharapkan terciptanya harmonisasi antara regulator dan pelaku pertanian.

3. Program Pemberdayaan Petani

Pemberdayaan disini berorientasi pada kemaslahatan masyarakat khususnya para petani. Adapun program pemberdayaannya meliputi: rapat berkala, Strategic Planning, Market Analysis/Analisis Pasar, Financial Planning/Perencanaan Keuangan dan Empowerin.

Rapat berkala dilakukan rapat antar petani yang dibantu oleh pemerintah, akademisi, praktisi, perwakilan masyarakat sebagai perwakilan konsumen, dan stakeholder lain yang terkait untuk membahas permasalahan, menentukan kesepakatan dan perencanaan strategis terkait pertanian.

Strategic Planning merupakan perencanaan strategis yang didapatkan berdasarkan rapat berkala. Perencanaan strategis memuat tentang Visi-Misi pertanian, serta manajemen pertanian meliputi pembagian tugas keorganisasian.

Pada kegiatan market analysis/analisis pasar, petani juga diharapkan mampu mengetahui aktivitas pasar mengenai tren yang sedang booming dan produk kreatif yang ia produksi, sehingga petani bukan hanya bisa berproduksi tapi juga dapat mengerti keadaan pasar (permintaan dan penawaran) terhadap barang yang diproduksinya.

Selanjutnya financial planning/perencanaan keuangan, perencanaan keuangan tentu menjadi program pemberdayaan yang juga tidak kalah penting, persiapan ini mendorong masyarakat memiliki perencanaan yang lebih tertata ketika hendak melakukan usaha jasa maupun dagang dalam bidang pariwisata dan industri kreatif setelah mandiri nanti. Pada fase ini pun masyarakat diberikan pelatihan terkait akuntansi pencatatan keuangan yang berhubungan dengan usaha jasa dan dagang.

Setelah para petani mandiri dari segi ekonomi, mereka diharapkan menjadi seorang enterpreneur yang kedepannya mampu berdiri sendiri bahkan memiliki usaha sendiri dan juga mampu melakukan pemberdayaan serupa kepada masyarakat setempat sehingga mampu meningkatkan taraf hidup masyarakat sekitar daerah pertanian ini merupakan program dari empowering.

4. Konsep Aplikasi Halal Tani

Aplikasi ini merupakan aplikasi terintegrasi yang dapat dijadikan sebagai sarana transaksi, edukasi, konsultasi dan berita ekonomi syariah tentang pertanian. Aplikasi ini berberbasis SMS, Website dan Android untuk memudahkan pertukaran informasi antara produsen (petani) dan konsumen. Pada aplikasi Halal Tani juga diterapkan prinsipprinsip syariah karena pada transaksi yang dilakukan oleh para produsen dan konsumen menggunakan akad-akad syariah. Tujuan penerapan prinsip-prinsip syariah ini adalah untuk menjaga keamanan setiap transaksi dari hal-hal yang dilarang oleh syariah seperti maysir, gharar, riba dan lain-lain. Hal ini yang sekaligus menjadi pembeda dengan fintechfintech sebelumnya. Berikut adalah fungsi dan konten fitur-fitur aplikasi Halal Tani:

a. SMS 
Layanan berbasis SMS yang berfungsi bagi para petani dan kosumen yang sudah mendaftarkan diri sebagai member pada Halal Tani akan mendapatkan SMS setiap harinya mengenai informasi daftar produk, harga produk, edukasi, ekonomi syariah (eksyar) dan berita pertanian.

Daftar produk berisi tentnag informasi mengenai beragam varian beras yang diproduksi oleh petani. Harga Produk berisi tentang informasi mengenai berbagai macam harga beras yang diproduksi oleh petani. Edukasi pada aplikasi ini memberikan informasi mengenai definisi pertanian, jenis padi dan jenis pupuk yang bagus untuk digunakan oleh para petani. Eksyar adalah informasi mengenai akad yang digunakan pada perdagnagan yang terdapat dalam aplikasi pertanian, serta berita mengenai ekonomi syariah terkait pertanian. Berita pertanian adalah informasi berupa berita pertanian terupdate yang ada di Indonesia serta negara lain.

\section{Gambar 2}

\section{Tampilan aplikasi SMS Halal Tani}
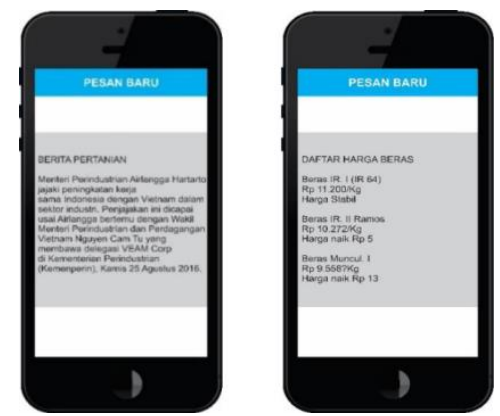

\section{b. Android dan Website}

Aplikasi ini menyediakan fitur-fitur yang menarik tidak hanya sebagai media untuk jual-beli beras namun juga memberikan edukasi dan memberi layanan konsultasi kepada para pengguna aplikasi ini.

\section{Gambar 3}

\section{Tampilan Menu Aplikasi Halal Tani}
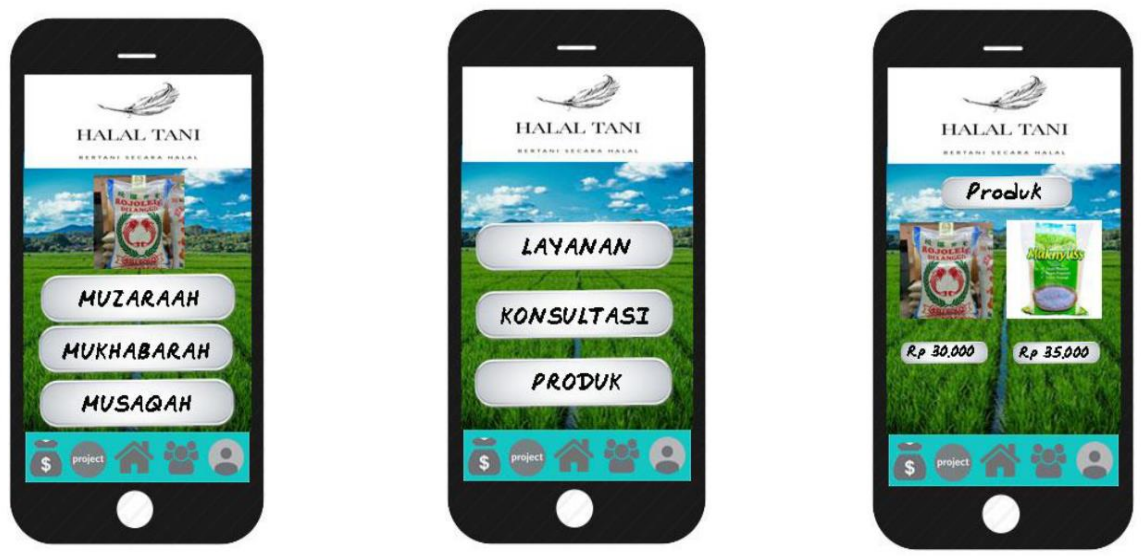

c. Transaksi 
Merupakan fitur yang memudahkan para konsumen untuk memilih produk mana yang akan dibeli dan memilih akad yang akan digunakan, selain itu fitur ini juga memudahkan bagi konsumen yang ingin menjadi investor untuk dapat berinvestasi di sektor pertanian. Aplikasi Halal Tani terdapat 3 akad yaitu akad Ba’i, akad Musyarakah dan akad Wakalah. Selain itu didukung dengan sub-fitur berupa biodata petani, lokasi, waktu tempuh yang dibutuhkan konsumen dan investor dalam melakukan transaksi sehingga transaksi menjadi lebih aman.

Pertama akad Ba'i, pada akad ini memberikan kemudahan pada produsen dan konsumen untuk melakuan transaksi jual beli terhadap produk yang tersedia. Dimana didalamnya terdapat sub-fitur aplikasi bagi konsumen sesuai dengan kebutuhan. Kedua fitur tersebut yaitu: Tunai dan as salam (pesanan). Fitur tunai menyajikan layanan transaksi dalam bentuk tunai antara produsen dengan konsumen. Fitur as salam memberikan layanan pesanan produk yang dibutuhkan konsumen yang sesuai dengan nilai-nilai syariah sehingga memudahkan konsumen dalam melakukan pemesanan produk beras.

Kedua musyarakah, akad ini memudahkan investor untuk dapat melakukan investasi pada sektor pertanian yang sesuai dengan prinsip syariah. Didalam fitur musyarakah, terdapat tiga sub-fitur aplikasi yang tersedia, yaitu: Muzara'ah yang menghubungkan kerjasama antara pemilik sawah atau lahan dengan petani selaku penggarap dimana bibit disediakan oleh petani selaku penggarap lahan. Kedua mukhabarah yakni kerjasama antara pemilik sawah atau lahan dengan petani selaku penggarap dimana bibit disediakan oleh petani selaku penggarap lahan. Selanjutnya Musaqah merupakan kerjasama antara pemilik lahan dan pengelola atau penggarap, untuk memelihara dan merawat lahan pertanian yang dimiliki oleh pemilik lahan. Ketiga wakalah, pada akad ini memberikan kesempatan bagi para konsumen dan investor luar negeri untuk melakukan transaksi.

Pada aplikasi halal tani juga dilengkapi biodata petani, informasi lokasi dan waktu tempuh. Biodata tani memberikan informasi mengenai biodata petani yang dibutuhkan konsumen dan investor dalam melakukan transaksi. Selanjutnya informasi lokasi memberikan informasi lokasi area lahan pertanian bagi para konsumen dan investor apabila ingin melakukan transaksi jual-beli As Salam dan Musyarakah. Terakhir waktu Tempuh memberikan informasi terkait waktu tempuh pengiriman produk dari produsen ke konsumen.

\section{d. Konsultasi}

Fitur dimana konsumen dan produsen dapat menanyakan seputar pertanian, dan yang dijawab oleh para pakar pertanian. Terdapat beberapa sub-fitur didalamnya seperti: Petani dan konseumen. Pada menu petani terdapat forum bagi para petani untuk dapat bertukar informasi terkait solusi dalam memecahkan masalah pada sektor pertanian. Selain itu sub-fitur ini juga memberikan kesempatan bagi para petani untuk dapat 
menjalin relasi secara luas. Dan menu konsumen merupakan forum bagi para konsumen untuk dapat berkonsultasi dan bertukar informasi terkait produk yang akan dikonsumsi.

e. Edukasi

Fitur yang menampilkan penjelasan tentang pertanian, berita terupdate mengenai perekonomian dan menegnai ekonomi syariah seperti: Berita yang memberikan informasi ter update terkait sektor pertanian baik dalam lingkup nasional maupun internasional. Berita pertanian yang menginformasikan edukasi pertanian bagi para konsumen dan produsen di sektor pertanian. Ekonomi Syariah berisikan tentang penjelasan informasi terhadap akad-akad dan syarat-syarat akad yang terdapat pada aplikasi.

\section{f. Consumer Service and Information}

Industri pertanian memiliki layanan yang memudahkan konsumen domestik dan mancanegara, layanan-layanan tersebut meliputi: produk yang dihasilkan petani, informasi grade dari kualitas hasil pertanian, tempat transaksi yang nyaman, serta dapat dijangkau dengan media elektronik, keterangan tentang produk halal/tidak halal, keterangan tentang harga dari setiap hasil pertanian dan sarana pendukung untuk melaksanakan transaksi jual-beli.

\section{Gambar 4}

Kelembagaan Aplikasi Halal Tani

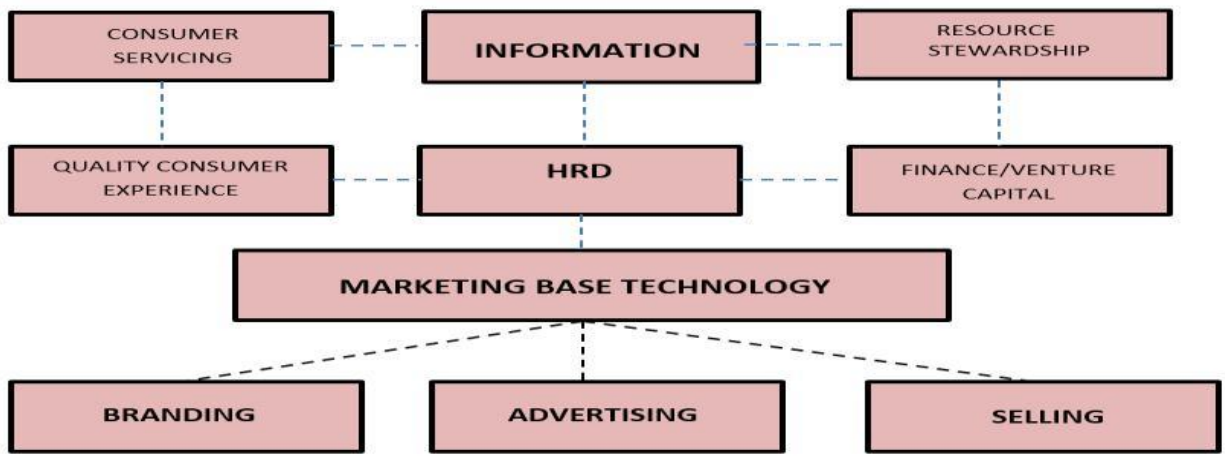

\section{Kesimpulan}

Pemberdayaan petani melalui aplikasi Halal Tani merupakan gagasan yang membeikan solusi kepada pelaku pertanian untuk memperluas jaringan pemasaran, kemudahan bertransaksi serta meningkatkan kualitas sumber daya manusia secara terintegrasi. Gagasan ini bertujuan untuk penguatan pembangunan kawasan pertanian khususnya di Provinsi Jawa Tengah dan bisa menjadi contoh bagi daerah lain untuk dapat meningkatkan pertumbuhan ekonomi di Indonesia. Dengan adanya kolaborasi dan sinergitas dari berbagai pihak maka diharapkan kemajuan pertanian berbasis syariah bisa memberikan dampak yang baik bagi pembangunan sektor pertanian di Provinsi Jawa Tengah yang dapat mensejahterahkan pelaku pertanian.

\section{Saran}

Penulis berharap pemerintah Provinsi Jawa Tengah dan stakeholders terkait berkomitmen untuk lebih memperhatikan sektor pertanian yang kondisi petaninya 
berbanding terbalik dengan potensi pertanian yang ada. Pemerintah daerah seharusnya memberikan dukungan berupa regulasi atau perangkat hukum yang jelas sehingga progam pemberdayaan petani dalam sektor pertanian melalui aplikasi Halal Tani dapat meningkatkan kesejahteraan pelaku pertanian baik dari sisi pendapatan maupun kualitas sumber daya manusia.

\section{DAFTAR PUSTAKA}

Agustono. (2013). Analisis sektor pertanian ditinjau dari peran terhadap pertumbuhan dan stabilitas produk domestik regional bruto di provinsi jawa tengah. Sepa, 9, 283296.

Bank Indonesia. 2016. Financial Technology (FinTech): Analisa Peluang Indonesia dalam Era Ekonomi Digital dari Aspek Infrastruktur, Teknologi, SDM, dan Regulasi Penyelenggara dan Pendukung Jasa Sistem Pembayaran. Dipresentasikan dalam Temu Ilmiah Nasional Peneliti, Bogor 28 Juli 2016.

Danu, A. E. (2015). Memahami Metode Penelitian Kualitatif Teori dan Praktik. Yogyakarta: Calpulis.

Farid, E. (2000). Membebaskan Yang Tertindas, penj. Watung A. Budiman. Bandung: Mizan.

Kementan RI. (2014). Rencana Strategis Kementerian Pertanian Pertanian Tahun 2015 2019. In Kementerian Pertanian RI. https://doi.org/351.077 Ind r

Lexy, M. J. (2013). Metodologi Penelitian Kualitatif. Bandung: PT Remaja Rosdakarya.

Qaradhawi Yusuf. (2002). Teologi Kemiskinan, penj. A. Maimun Syamsuddin dan A. Wabid Hasan. Yogyakarta: Mitra Pustaka.

Suwanti, \& Gunanto, E. Y. A. (2013). Analisis pengaruh pengeluaran pemerintah untuk sektor pertanian terhadap pdrb sektor pertanian 35 kabupaten/kota di provinsi jawa tengah tahun 2007-2010. Diponegoro journal of economics, 2(4), 1-10. Retrieved from http://ejournal-s1.undip.ac.id/index.php/jme

Tamyawan, S. (2012). Analisis Potensi Sektor Pertanian Kabupaten Dan Kota Di Provinsi Jawa Tengah (Analisis Data Pdrb Provinsi Jawa Tengah Tabun 2004 - 2008). UNS (Sebelas Maret University). 